\title{
Efforts to Improve the Creative Economy during the Covid-19 Pandemic in ASEAN
} Countries

\author{
Jovin Palla $^{1}$, Kainoa Strickler ${ }^{1}$ \\ Business Administration Department, Assumption College, Philippines \\ Received: January 13, 2021 \\ Revised: February 28, 2021 \\ Accepted: March 14, 2021
}

\begin{abstract}
Increasing the creative economy during the pandemic is very urgent, as an effort to stabilize the economy in ASEAN. The character of the creative economy is characterized by economic activities that are based on the exploration and exploitation of creative ideas that have high selling value. All tourism ministers from ASEAN countries to strengthen tourism cooperation, one of the economic sectors hardest hit in the pandemic. Intelligent marketing is needed in order to know the strengths of our competitors and market tastes, because in the era of globalization, war is actually a war in the economic field and the creative economy is the main weapon. Strong cooperation in efforts to jointly handle the impact of COVID-19 in the tourism sector in the ASEAN region. All ASEAN members to jointly enhance cooperation not only in dealing with pandemic problems but also in terms of developing the creative economy.
\end{abstract}

Keywords: Creative Economy, Covid-19 Pandemic, Cooperation

\section{Introduction}

The artistic economy, which includes apparel, architecture, music, video, and other digital games, needs to be nurtured as a strategic option. Gangnam style has already shown how innovation will provide a fresh source of growth for South Korea. We are not exaggerating when we say that a modern economies are based on intellectual property including patents, copyrights, trademarks, and prototypes have arisen. To support global economic development, the innovative economy will become the locomotive. As we all know, Indonesia recently had the World Conference on the Creative Economy (WCCE) in Bali, where delegates from the public, the private sector, and NGOs came together. Indonesia's membership in the WCCE seeks to enable the creative industry to expand and diversify it with its cultsural diversity and population bonus.

The 4.0 technological revolution has spawned fundamental improvements on both sides of the globe, including increasing rivalry from information technologies across almost every facet of business. As a result of these exponential developments, the frontiers of economic competitiveness are shifting to include the increasing usage of artificial intelligence (AI), new kinds of human-machine interfaces, and the spread of the shared economy. The current phase of the industrial revolution, Version 4.0, emphasizes continuing progress and creation of new value by capitalizing on innovative innovations is considered one of the most important steps in our strategic strategy to succeed in global competition.

With the publication of "The Artistic Economy: How Individuals Profit from Sharing in the New World of Show-Selling Ideas" by John Howkins, the business of becoming creative has been widespread. Howkins first used the word "creative economy" to describe the new wave of creative businesses that was spreading throughout the country the current economic wave is supported by economic activity; it is the activity of thoughts rather than of simple supply and demand Howkins' projections for the advent of a modern business prosperity in the U.S. are 
exaggerated. Last year in the U.S. alone, it received USD 414 billion in sales from products and services purely from the application of imagination.

The concept of the creative economy, therefore, can be described as the various theories of the multifaceted nature of significance that a significant life events provide for those involved in the creative process. The creative economy is creative values being generated as a consequence of concept (Toma et al., 2018; Skavronska, 2017; Moore, 2014). The economic activity of the creative industry is shown through projects focused on exploratory and commercial concepts (Lenfle, 2008; Hotho \& Champion, 2011).

In the book Education and the Creative Economy, the creative economy is an economic philosophy that builds on concepts and experience. Efficient use of ideas and resources depend on information and innovation (human resources) as the primary means of economic productivity.

\section{The Importance of Developing the Creative Economy}

Everybody should see where we're going to be a part of the concrete plans to achieve a lasting change such that the inclusive benefits of strategic problems like social stability, marketing, habitats, and innovative finance can have a meaningful impact on the sustainability of the creative economy. The rapid advancement of the fourth industrial revolution is gradually leads to the usage of information technology.

Geographical boundaries have been irrelevant. Many citizens are empowered to work together to further improve Indonesia's place in the creative economy with the internet and other cuttingedge technology. Culture, the arts, and handicrafts, and business enterprise growth, may all be very effective when used as a source of capital to solve the issues of economic injustice and social welfare (Davis, 2002; Gibb, 1987). Using the WCCE as a learning tool for the local creative economy should include the participation of global suppliers such as Grab, TikTok, Shopee, and Potato Head, as they were all present in an operation of the same name on it.

There were also initiatives in the attempt to encourage and develop the national Creative Economy Agency environment at the case, including the National Initiative for the Arts and Culture and Innovation (NIAC) program. Any of these initiatives include Akatara, which consists of developers and producers meeting; Unity Developer Day, a program that brings dishes from Indonesia to the attention of others; and Bekraf, which is an opportunity for investors and producers to interact.

The 2018 Economic Yearbook predicts that 2019 will be the year of creative-sector dynamism for Indonesia, as increasing numbers of millennial expand businesses to the economy's derivatives subsectors. The creative economy can be a major driver of development due to the wealth of its assets. In the last three years, the growth in the contribution of the creative industry to the GDP in Indonesia has continued. In 2017, the creative sector, Gross Domestic Product, 685 billion USD was applied to the amount of GDP.

The total value of last year was \$576 billion USD, and it rose to \$615 billion USD in 2015. This business employed 16.4 million people in 2017, which was better than the 16.2 million in 2015 and better than 16.96 million in 2016. This accomplishment will act as a catalyst to move Indonesia into the creative industry in the future. This business argument is not a wild and unsubstantiated generalization given the potency of Indonesia's innovative economy is already seen in the world.

Andrea Hirata's first book was turned into a film because it reinvigorated the economy in Belitung. Gojek has begun to reach Vietnam and Singapore as well as Jubeid's concrete

Copyright @ 0 2021, Journal of Asian Multicultural Research for Economy and Management Study, Under the license CC BY-SA 4.0 
distribution and factory outlets to mention the Bandung outlet is. It isn't an illusion to say that Indonesia's economic future might be much brighter if it rates as a little higher in the world in today's rankings, albeit not a fresh, if it is likely to climb to seventh by 2030, as the McKinsey Global Institute forecasts. Today Indonesia has over 45 million engaged users, with a booming population in metropolitan regions, giving it great economic power.

\section{Strategy for Increasing the Creative Economy}

The artistic sector, like the general economy, poses many challenges. One major obstacle for all creative industry folks, particularly those who are in the initial stages of their careers, is the difficulty of operating within the regulations. Legal regulations relating to innovation and entrepreneurship are absolutely essential to maintaining a creative economy (IPR) (Lee, 2000). In the artistic sector, intellectual property is valuable since it is essential. Particularly in the area of music and video, piracy is abundant because of the vague IPR regulations.

Ever since the invention of sound and motion pictures, piracy has plagued the recording and movie industries, to this day. It is important to continue to cultivate an environment that nurtures the spirit of entrepreneurial and innovative businesses by developing a set of tools for potential leaders and by fostering dialogue opportunities at the roots of the industry as well as growing new plantings that extends this globally in order to different locations.

The character of the economy is evolving quickly; in order to respond to this, government policy must implement constant deregulation to help both international and domestic players. There are priceless lessons to be learnt from the sharing economy that involves a business like Uber, since it does not control vehicle infrastructure but is effective regardless. Because of technologies and the internet sharing, this paradigm reduces costs. However, by taking the output out of books away from the equation, Amazon has enabled it to bind customers and suppliers even more rapidly and effectively.

Similarly, the idea of "Online to Offline" places like restaurants use online facilities. Advances of technologies, computers, devices, and the internet have brought about modern approaches to product design (Parsons, 2009; Li et al., 2017; DeSanctis \& Poole, 1994).In the forthcoming Industrial Revolution 4.0, development would have to shift closer to the consumers so that it can be more nimble and flexible, not just the size of information technology.

Country like Indonesia, for example, has tremendous geographical and human capital matched to the world's creativity, which has great potential to be used as a modern driver of national economic growth. As a result, it is imperative to collaborate with all stakeholders involved in the economy's development. Policymakers are required to look at the current challenges and present proposals to assist with priority size, emphasis, and observable growth of the creative industry. The two levels of government (central and regional) must come together to integrate a common strategy for the growth of the creative economy to gain widespread acceptance. A creative economy offers the promise of greater opportunity for entrepreneurs, which they hope would aid their promotion, is seen as a means of capital support, and gives spirit to start-ups.

\section{Efforts to Increase the Creative Economy during the Pandemic}

According to one research, ASEAN member countries have agreed to adopt seven collaboration measures in the travel and tourism field in order to minimize the threat of the COVID-19 pandemic. The Deputy Minister of Tourism and the Creative Economy, Angela Tanoesedjo, attended the "special ASEAN Tourism Ministers'Meeting on Coron" (COV-2019) on Wednesday (April 29, 2020). 
The effect of COVID would have to be tackled jointly in Southeast Asia. It is the right time for us all ASEAN countries to come together when we join together, we can be more strong. Both ASEAN tourism ministers meeting to reduce the impact of the pandemic, one of the most economically affected sectors

concluded that in accelerating the sharing of travel health requirements and other actions the governments of member countries should take to slow down the CO19-linked outbreak (ATCCT).

Continue to nurture closer cooperation between the ASEAN national tourism organizations (particularly in the fields of health, intelligence, and transportation, and in cooperation with other ASEAN sectors as well) and other ASEAN agencies, especially with external ASEAN partners. Responding and minimize COVID-19 and other potential emergencies quickly

Asean member countries have decided on seven tourism prevention measures to counteract the COVENID-19 virus. In the meeting of the Special Meeting of ASEAN Tourism Ministers, Deputy Minister of Tourism and Creative Economy (Wamenpar) Angela delivered a speech on a new method of avoiding the scourge of Coronavirus (COVID-19). It is essential that strong cooperation is needed to address the impact of COVID in the ASEAN tourism. It's almost time for all ASEAN countries to be as one. I believe you and I will help each other to build a brighter future.

Additional business capacity could be provided through application of creative thinking, experimentation in market penetration, out-out-of-the-the-the-box thinking, and a dedication to network-based development, the implementation of varied, creative, and green practices. In the worldwide marketplace of ideas, we are forced to use the tools of marketing in new ways as well.

We don't only deal with selling merchandise but also in packaging tactics, segmentation, targeting, and promotion strategies. We need intelligent messaging so that we recognize the power of our competition and customer preferences are variable. We live in an age when economic warfare is really isn't practical anymore. We surely hope that Indonesia's contribution to the creative industry can further improve people's health as it evolves into the country's creative future.

Despite the country's economic development becoming the fastest in Southeast Asia, Indonesia still produces artistic goods of international quality. Cooperatives should serve those that are in the middle- and lower-income levels of the economy because that field is critical to the overall economic stability. Promoting peace and cooperation all ASEAN members when we speak to "the next generation," we sometimes refer to those as "students" for shorthand, but in reality we're referring to those that will someday take over as well. Furthermore, we must suggest changing the institutional process, reestablishing law and order, unify cultural visions, and drive productivity in all of our structures. ASEAN collaboration includes continuity, tolerance, reciprocal confidence, and unity, but often demands a certain degree of fluidity to implement. Creative processes (those which focus on the community) need multiple partnerships in several industries (everyone-centered approach (multisector).

\section{Conclusion}

A strong supportive framework for innovation and entrepreneurship in the creative economy calls for clear legislative guidelines around Intellectual Property rules Everybody should see where we're going to be a part of the concrete plans to achieve a lasting change such that the inclusive benefits of strategic problems like social stability, marketing, habitats, and

Copyright @ $\odot$ 2021, Journal of Asian Multicultural Research for Economy and Management Study, Under the license CC BY-SA 4.0 
innovative finance can have a meaningful impact on the sustainability of the creative economy. The artistic sector, like the general economy, poses many challenges. The biggest complaint regarding legislation by small businesses that are still in the startup phase is that they are not flexible enough to meet the needs of the creative industries.

\section{References}

Davis, S. M. (2002). Social entrepreneurship: Towards an entrepreneurial culture for social and economic development. Available at SSRN 978868.

DeSanctis, G., \& Poole, M. S. (1994). Capturing the complexity in advanced technology use: Adaptive structuration theory. Organization science, 5(2), 121-147.

Gibb, A. A. (1987). Enterprise culture-its meaning and implications for education and training. Journal of european industrial training.

Hotho, S., \& Champion, K. (2011). Small businesses in the new creative industries: innovation as a people management challenge. Management Decision.

Lee, C. M. (2000). The Silicon Valley edge: A habitat for innovation and entrepreneurship. Stanford University Press.

Lenfle, S. (2008). Exploration and project management. International Journal of Project Management, 26(5), 469-478.

Li, J. Q., Yu, F. R., Deng, G., Luo, C., Ming, Z., \& Yan, Q. (2017). Industrial internet: A survey on the enabling technologies, applications, and challenges. IEEE Communications Surveys \& Tutorials, 19(3), 1504-1526.

Moore, I. (2014). Cultural and Creative Industries concept-a historical perspective. ProcediaSocial and Behavioral Sciences, 110, 738-746.

Parsons, T. (2009). Thinking: Objects: Contemporary approaches to product design (Vol. 18). AVA publishing.

Skavronska, I. V. (2017). Creative industries in Ukraine: analysis and prospects of the development. Economics \& Sociology, 10(2), 87.

Toma, S. G., Peptenatu, D., Andronache, I., Ahammer, H., Pintilii, R. D., Drăghici, C. C., \& Simion, A. G. (2018). The creative economy in Romania, a key factor of economic integration in the European Union. In Doing Business in Europe (pp. 329-350). Springer, Cham. 